\title{
Variability and Trends of Daily Heavy Rainfall Events over Niger River Basin Development Authority Area in Nigeria
}

\author{
Joseph Sunday Babatolu¹, Rufus Temidayo Akinnubi², Akintade Taiwo Folagimi ${ }^{3}$, \\ Omosuyi Oluwayemisi Bukola1 \\ ${ }^{1}$ Department of Geography, Adeyemi College of Education, Ondo, Nigeria \\ ${ }^{2}$ Department of Physics, Adeyemi College of Education, Ondo, Nigeria \\ ${ }^{3}$ Department of Agricultural Science, Adeyemi College of Education, Ondo, Nigeria \\ Email: rufus782000@yahoo.com
}

Received 20 August 2013; revised 22 September 2013; accepted 23 October 2013

Copyright (C) 2014 by authors and Scientific Research Publishing Inc.

This work is licensed under the Creative Commons Attribution International License (CC BY).

http://creativecommons.org/licenses/by/4.0/

c) (i) Open Access

\begin{abstract}
Using 70 years of daily rainfall records in eight stations, an analysis of variability and trends of daily heavy rainfall events over Niger River Basin Development Authority Area was carried out by using Standardized Anomaly Index and Spearman Rank Correlation Coefficient. Significant temporal variability on interannual and decadal time-scales was observed in the frequency of heavy rainfall events and annual heavy rainfall amount. Both the annual heavy rainfall amount and frequency of heavy rainfall events demonstrated no pronounced temporal decreasing or increasing trend. However, more recent data records from 1981 onwards revealed an increasing trend. Thus, evidence of a temporal change is apparent in heavy rainfall events in the last three decades in sympathy with global warming.
\end{abstract}

\section{Keywords}

Rainfall; Anomalies; River Niger Basin Development Authority Area

\section{Introduction}

Scientists have suggested that temperature changes will increase the average worldwide rainfall; but decrease rain in some areas as rainfall is tied to temperature changes and the amount of light reaching the earth. IPCC [1] reported that the observed increasing air temperature over several decades is associated with changes in some of the components of the hydrological cycle such as increasing atmospheric water vapour, increasing evaporation,

How to cite this paper: Babatolu, J.S., Akinnubi, R.T., Folagimi, A.T. and Bukola, O.O. (2014) Variability and Trends of Daily Heavy Rainfall Events over Niger River Basin Development Authority Area in Nigeria. American Journal of Climate Change, 3, 1-7. http://dx.doi.org/10.4236/ajcc.2014.31001 
changing precipitation patterns, intensity and extremes. Warmer temperatures are very likely to produce more vigorous hydrological cycles so that increase in air temperature are likely to increase evaporation, capacity of air to hold more moisture and thus heavier rainstorms. A warmer and moister atmosphere should lead to more dynamic hydrological cycle and thus a greater atmospheric instability, resulting in more extreme events [2]. It has been shown that an increase in atmospheric moisture content is more likely to result in an increase in rain per rain day rather than in the number of rain-days in many areas of the globe [3].

There is increasing evidence that global warming is globally changing precipitation and the hydrological cycles especially extremes. The International Panel on Climate Change [1] states that the overall conclusion from observational and modeling studies is that an increase in the frequency of heavy precipitation events is likely to have occurred over most land areas during the 20th century. Trenberth [4] concluded that there is a direct influence of global warming on changes in heavy rains and precipitation. Trend analyses of heavy precipitation in many parts of the world have been conducted. It has been observed that extreme climate events are indeed increasing at a faster rate relative to the mean climate change worldwide [5]-[7]. It has also been observed that the variability of extreme climate events shows strong regional features [6] [8]. For instances, Groisman [9] detected an increase in heavy precipitation $(>25.4 \mathrm{~mm})$ in Western Norway. An increasing trend was detected by Bruneith [10] for Italy during the 20th century. Over Southern Canada, Daithi [2] found an increasing trend in total precipitation that results from increases in all levels of event intensity during the 20th century and increases concentrated in heavy and intermediate events during the latter half of the century with the largest occurring in Arctic areas. Chen [11] reported a weak linear trend of heavy rainfall events over eastern China but a significant decadal variability during 1960-2009 in the region. The frequency of heavy rainfall events has also been reported to increase in Japan [12], while in the United Kingdom, heavy rainfall events have been observed to decrease [13].

In Africa, there is an observed significant increase in intensity of extreme rainfall events between 1931-60 and 1961-90 in about 70\% of South Africa [14]. A significant decline in the frequency of all size categories at the more northerly station in Sudan was reported by Walsh et al. (1988). A similar result was reported for northern Nigeria where Olaniran [14] detected a significant decrease in heavy rainfall (>25.4 mm) series for the midland and Sahel zones. A negative trend in heavy rainfall event was reported by Babatolu [15] for the Niger River Basin Development Authority Area, Nigeria during the period 1931-1990.

Floods which are associated with extremes in rainfall are becoming frequent in Nigeria in the last fifteen years. Daily newspaper headlines of floods reflect the importance of precipitation in human affairs. Flood damages are in millions of Naira annually with thousands of lives lost. An example is the unprecedented extreme flood in the rivers Niger and Benue basins in 2012 that set the stage for the costly, lingering and extensive inundation in September/October 2012. Many settlements were submerged, numerous farms were washed away and several million people were displaced. Milly [16] found that great floods have increased worldwide in the twentieth century and are connected with heavy precipitation events [17].

These events may be evidence of increasing frequency and intensity of heavy rainfall events attributable to global warming. As noted earlier, precipitation is an important element of climate which impinges directly and significantly on humanity. Little variations or changes in precipitation bring enormous economic, environmental, social and political repercussions. To this end, an analysis of occurrence of heavy rainfall events is imperative. This report, therefore, seeks, in part, to update the analysis of the amount and frequency of heavy rainfall event in the country. Again, in the context of climate change due to global warming, analysis of the variability in amount and frequency of heavy rainfall event series is an additional means of monitoring such climate change. It has been suggested that tests for climate change should focus on changes in extreme events rather than on changes in climate mean [18].

\section{Materials and Method}

\subsection{The Study Area}

Niger River Basin Development Authority Area (NRBDA) is located between latitude $7^{\circ} \mathrm{N}$ and $12^{\circ} \mathrm{N}$ and between longitudes $3^{\circ} \mathrm{E}$ and $9^{\circ} \mathrm{E}$ in Nigeria (Figures 1 and 2). Its altitudes range from 300 to about $1200 \mathrm{~m}$ with a much contrasted relief. The climate is controlled by the moist maritime south-westerly monsoon from the Atlantic Ocean which brings rains to this area between March and October and the dry continental north-easterly wind from the Sahara desert which brings dryness between November and March. The 1941-2010 mean annual rainfall 


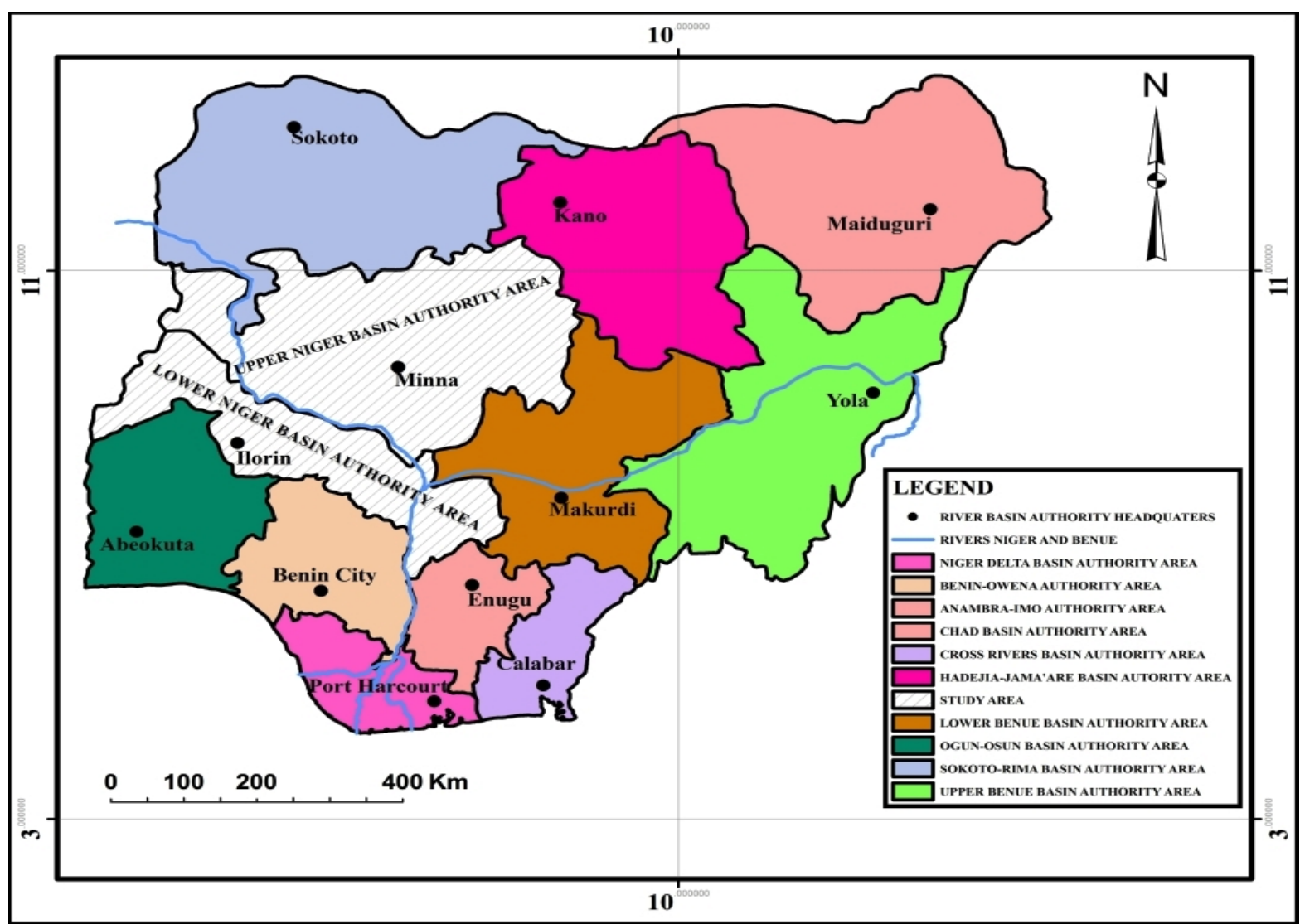

Figure 1. Map of Nigeria showing the upper and lower Niger river basin development authorities.

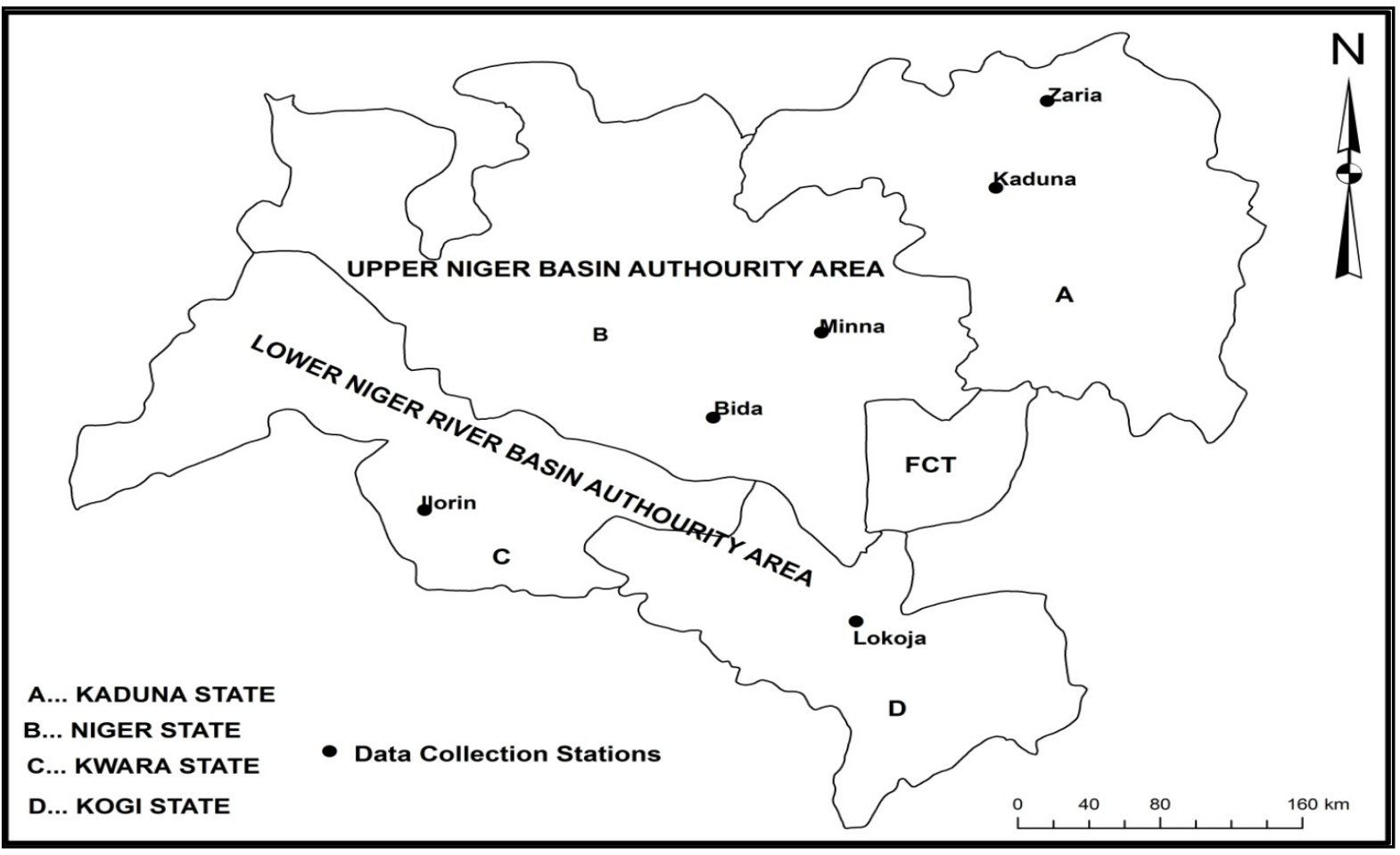

Figure 2. Map of the upper and lower Niger river basin development authorities showing climate data collection stations. 
ranges between $1040 \mathrm{~mm}$ in the north and $1260 \mathrm{~mm}$ in the north-east. The mean annual temperature during the period $1950-2010$ ranges between $25.6^{\circ} \mathrm{C}$ and $27.9^{\circ} \mathrm{C}$.

Guinea Savanna forms the main vegetation of the NRBDA area covering virtually all the region except the river Niger flood plain. The vegetation decreases in luxuriance north ward in sympathy with rainfall. The southern part of this vegetation zone has dense woodland where trees and shrubs form a fairly close canopy.

NRBDA is drained by many streams the most important being Kaduna, Gurara, Kampe, Ero, Moshi, Awon and Kontagora. The study area also houses the important hydroelectric power stations of the country-kainji, Jebba and Shiroro.

\subsection{Data and Data Processing}

Rainfall data have been collected for the period 1941-2010 for eight stations and heavy rainfall series have been generated for each station. The stations were selected on the basis of length and continuity of records and the desire to have data points distributed fairly uniform over the study area.

For this study the daily rainfall were split into three categories, light $(<10.4 \mathrm{~mm})$, moderate $(10.4-25.4 \mathrm{~mm})$ and heavy $(>25.4 \mathrm{~mm}$ ) following Ilesanmi [19]. The area-average frequency of heavy rainfall events and heavy rainfall amount were contrasted between the 1941-80 and 1981-2010 sub-periods in addition to the base period to investigate the trend in heavy rainfall series.

\subsection{Statistical Techniques}

Each of the station's annual frequency of heavy rainfall and heavy rainfall amount were redefined as the number of standard deviations away from the mean (z-scores). These z-scores are then averaged directly for all stations in the region in order to get area-average. This is a common index (standardized Anomaly Index) used for regional climate studies.

Each of the regional annual number of heavy rainfall events and heavy rainfall amount were also examined for trends using the Spearman's rank correlation coefficient. The long-term trends were first investigated for the period 1941-2010 and for two other sub-periods, 1941-1980 and 1981-2010.

\section{Results}

\subsection{Variability of Annual Heavy Rainfall Amount in NRBDA Area}

The annual heavy rainfall amount variability in the NRBDA area (Figure 3(a)) shows diverse temporal patterns of occurrence. Two distinct periods of annual heavy rainfall amount anomalies of different type can be recognized. These periods vary in severity and length. The annual heavy rainfall was below long-term mean from 1941 to 1984 with strongest negative anomalies thus demonstrating pronounced decrease during the period. The negative anomalies were very strong mostly above one standard deviation while the positive ones were all below one standard deviation except for three years during the period.

There is a run of good years of annual heavy rainfall amount during the period 1985-2010. Annual heavy rainfall amount during this period was above the long-term mean. Though there was no persistence of anomaly of a particular type, there was preponderance of strong positive anomalies during this period. Most of these positive anomalies are above one standard deviation.

The most noticeable feature of the temporal variability of annual heavy rainfall amount in the study area is that it is dominated by interannual variability whereby the above mean heavy rainfall amount years rapidly alternate with below mean heavy rainfall amount years. The year to year variability is relatively pronounced. Long and persistent below and above long-term mean of five years and above are absent and this is inconsistent with the decadal scale variability exhibited by the annual rainfall in the study area.

\subsection{Variability of Annual Frequency of Heavy Rainfall Events in the NRBDA Areas}

Figure 3(b) depicts the temporal variability of the annual frequency of heavy rainfall events during 1941-2010 in the NRBDA area. It shows four distinct periods when the annual frequency of heavy rainfall events anomalies of a particular type was most persistent. The period 1941-50 is one with few number of heavy rainfall events. The frequency of heavy rainfall was below long-term average with strong negative departure in eight out of the 


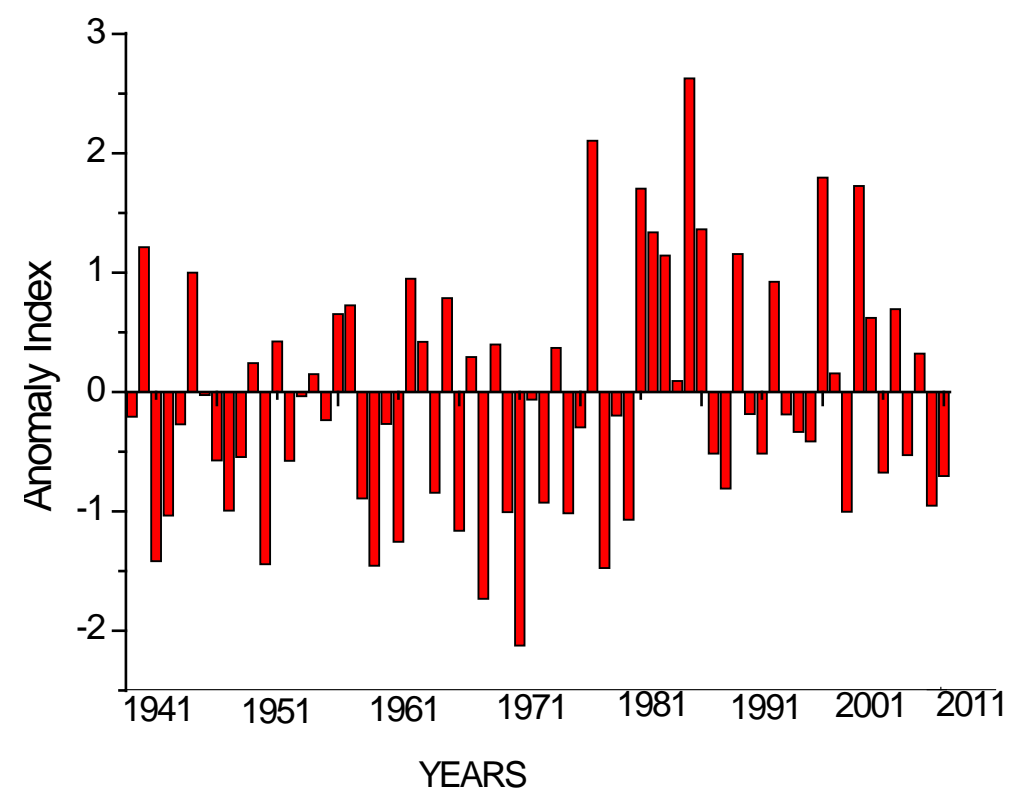

(a)

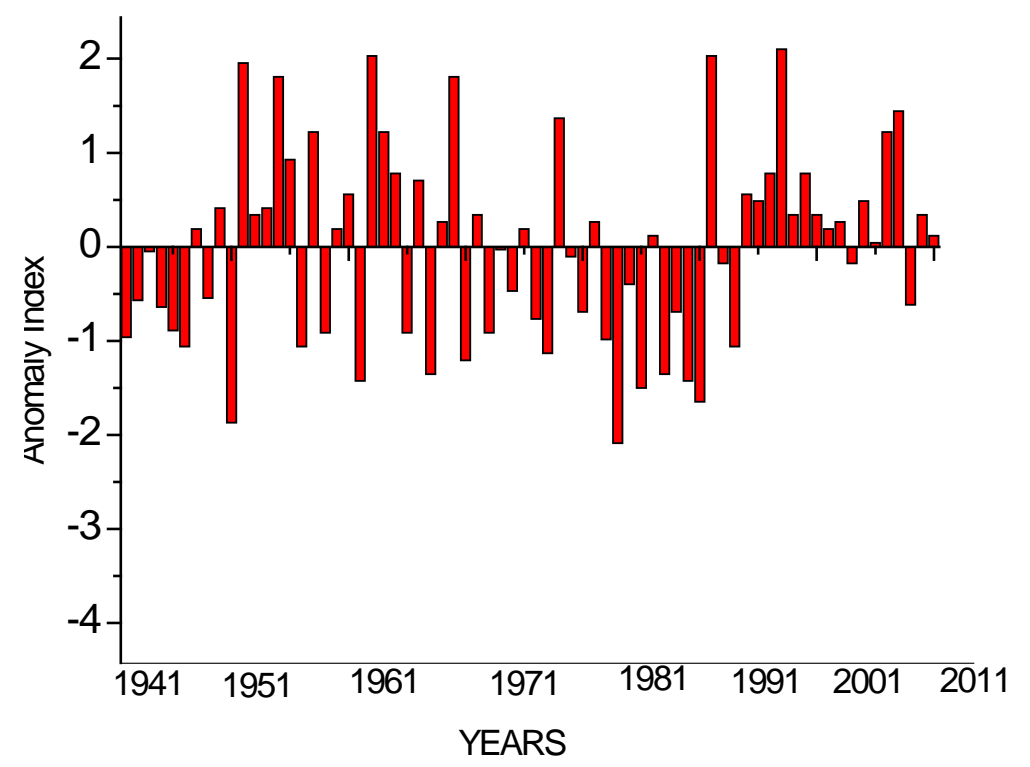

(b)

Figure 3. (a) Annual heavy rainfall anomalies in the upper and lower Niger River basin development authority area; (b) Annual frequency of heavy rainfall anomalies in the upper and lower Niger River basin development authority area.

ten-year period. In contrast, the heavy rainfall events became progressively more frequent from 1951-1968. This period was one of above average frequency of heavy rainfall events. The progressive increase of this period was checked during the period 1969-1990 when the heavy rainfall events became significantly less; frequency of heavy rainfall was persistently below the long-term average. Out of the twenty one year's within this period, only five were weakly above average. Frequency of heavy rainfall events increased again as from 1991 as the 1991-2010 was dominated by above average anomalies.

It is notable that the temporal variability of the number of heavy rainfall events is characterized by alternating wet and dry conditions on multi-decadal timescale. The temporal variability pattern reflected annual rainfall but contrasted with the heavy rainfall amount which was dominated by short-term above and below average conditions. 
Table 1. Trends in annual heavy rainfall amount and frequency of heavy rainfall events over the NRBDA area.

\begin{tabular}{ccc}
\hline Rainfall attribute & $\mathbf{1 9 4 1 - 2 0 1 0}$ & $\mathbf{1 9 8 0 - 2 0 1 0}$ \\
\hline Heavy rainfall amount & 0.0300 & 0.5026 \\
Frequency of heavy rainfall events & 0.1439 & 0.5027 \\
\hline
\end{tabular}

\subsection{Trends in Annual Heavy Rainfall Amount and Frequency of Heavy Rainfall Events in the NRBDA Area}

The analyses in Figures 3(a) and 3(b) show an overall increasing trend in both annual heavy rainfall amount and frequency of heavy rainfall events. The observed trends were tested for significance using Spearman’s rank correlation coefficient (Table 1).

The test shows that both the annual heavy rainfall amount and frequency of heavy rainfall events during the period 1941-2010 demonstrated no pronounced temporal decreasing or increasing trends. The statistically insignificant trend in the rainfall attributes during the period 1941-2010 may be accounted for by the large temporal variability that characterized the rainfall attributes series.

On the other hand, both heavy rainfall amount and frequency of heavy rainfall events exhibit statistically significant increasing trend during the period 1980-2010. The increase in heavy rainfall in the last three decades may be attributed to global warming. A warmer and moister atmosphere should lead to a more dynamic hydrological cycle and thus a greater atmospheric instability, resulting in more extreme events [2]. Moreover, an increase in atmospheric moisture content is more likely to result in an increase in rain per rain day rather than in the number of rain-days in many areas of the globe (Fowler and Hennessy, 1995). Gellens (2000) reported an increase in extreme precipitation in Belgium during the period 1951-1995, but no such trend was found for the period 1910-1995. Chen [11] found a weak linear trend of heavy rainfall events over eastern China during 19602009.

Variations in annual rainfall, heavy rainfall amount, and frequency of rainfall events over NRBDA area since 1980 are dominated by an increasing trend in sympathy with increasing temperatures. This suggests that global warming may have direct effect on changes in precipitation and heavy rains as noted by Trenberth [4].

\section{Conclusions}

This study has added to the increasing evidence that human-induced climate change (global warming) is changing precipitation especially the heavy and extreme precipitation globally. Climate characteristic of heavy rainfall variability combined with a poor level of infrastructural development has resulted in high vulnerability, particularly of rural communities, to extreme climate events such as droughts and floods.

The society's vulnerability to extreme weather and climate scenarios such as flood and drought is illustrated by the impacts of the drought of 1972/73 and the flood of 2012 on the flood plains of rivers in Niger and Benue and their tributaries. Given the vulnerability of communities in Nigeria, changes in the frequency and magnitude of heavy rainfall events resulting from global warming could have serious implications. Minimizing the problem of floods and droughts, therefore, makes for major challenges for water managers. It behoves on water managers and the government to save in times of excess for those times when there is too little.

\section{Acknowledgements}

The authors appreciated TETFUND whose financial support make this study possible. The authors also acknowledge the Nigeria Meteorological Agency for the temperature data.

\section{References}

[1] Intergovernmental Panel on Climate Change (IPCC) (2007) Impacts, Adaptation and Vulnerability. Contribution of working group II to the fourth Assessment Report of the Intergovernmental Panel on Climate Change. Cambridge University Press, Cambridge.

[2] Daithi, A.S., Andrew, J.W. and Francis, W.Z. (2000) Trends in Canadian Precipitation Intensity. Atmosphere-Ocean, 
38, 321-347. http://dx.doi.org/10.1080/07055900.2000.9649651

[3] Fowler, A.M. and Hennessy, K.J. (1995) Potential Impacts of Global Warming on the Frequency and Magnitude of Heavy Precipitation. Natural Hazards, 11, 283-303. http://dx.doi.org/10.1007/BF00613411

[4] Trenberth, K.E. (2005) The Impact of Climate Change and Variability on Heavy Precipitation, Floods and Droughts. In M. G. Anderson (Ed), Encyclopedia of Hydrological Sciences. John Wiley and Sons Ltd., Hoboken.

[5] Karl, T.R. and Kmight, R.W. (1998) Secular Trends of Precipitation Amount Frequency and Intensity in the United States. Bulletin of the American Meteorological Society, 79, 231-241. http://dx.doi.org/10.1175/1520-0477(1998)079<0231:STOPAF>2.0.CO;2

[6] Alexander, L.V., Zhang, X., Peterson, T.C., Caesar, J., Gleason, B., Klein Tank, A., Haylock, M., Collins, D., Trevin, B., Rahimdah, F., et al. (2006) Global Observed Changes in Daily Climate Extremes of Temperature and Precipitation. Journal of Geophysical Research, III D05109, http://dx.doi.org/10.1029/2005JD006290

[7] Qian, W.H., Fu, J.L. and Zhang, W.W. (2007) Changes in Mean Climate and Extreme Climate in China during the Last 40 Years. Advanced Earth Sciences, 22, 673-684.

[8] Sun, F.H., Yang, S.Y. and Ren, G.G. (2007) Decade Variations of Precipitation Event Frequency Intensity and Duration in Northeast China Journal of Applied Meteorological Science, 18, 610-618.

[9] Groisman, P.Y.A., Karl, T.R., Easterling, D.R., Kmight R.W., Jamason, P.F., Hennessy, K.J., Suppiah, R., Page, C.M., Wibig, J., Fortunlak, K., Razuvaev, V.N., Douglas, A., Forland, E. and Zhal, P.M. (1999) Changes in the Probability of Heavy Precipitation: Important Indicators of Climatic Change. Climate Change, 42, 243-283. http://dx.doi.org/10.1023/A:1005432803188

[10] Brunetti, M., Buffoni, L., Mangeri, M. and Nanni, T. (2000) Precipitation Intensity Trends in Northern Italy. International Journal of Climatology, 20, 1017-1031. http://dx.doi.org/10.1002/1097-0088(200007)20:9<1017::AID-JOC515>3.0.CO;2-S

[11] Chen, H., Sun, J. and Fan, K. (2012) Decadal Features of Heavy Rainfall Events in Eastern China. Acta Meteorological Simca, 26, 289-303. http://dx.doi.org/10.1007/s13351-012-0303-0

[12] Iwashima, T. and Yamamato, R. (1993) A Statistical Analysis of the Extreme Events: Long-Term Trend of Heavy Daily Precipitation. Journal of the Meteorological Society of Japan, 71, 637-640.

[13] Osborn, T.J., Hulme, M., Jones, P.D. and Basnett, T.A. (2000) Observed Trends in the Daily Intensity of United Kingdom Precipitation. International Journal of Climatology, 20, 347-364. http://dx.doi.org/10.1002/(SICI)1097-0088(20000330)20:4<347::AID-JOC475>3.0.CO;2-C

[14] Olaniran, O.J. (1991) Evidence of Climate Change in Nigeria Based on Annual Series of Rainfall of Different Daily Amount, 1919-1985. Climate Change, 19, 319-341. http://dx.doi.org/10.1007/BF00140169

[15] Babatolu, J.S. (1998) Climate Change and Its Implication for Water Supply in the Niger River Basin Development Authority Area. An Unpublished Ph.D. Thesis Submitted to the Department of Geography, University of Ilorin, Ilorin.

[16] Milly, P.C.D., Wetherald R.T., Dume, K.A. and Delworth, T.L. (2002) Increasing Risk of Great Floods in a Changing Climate. Nature, 415, 514-517. http://dx.doi.org/10.1038/415514a

[17] Muller, M., Kaspar, M. and Matschullat, J. (2009) Heavy Rains and Extreme Rainfall-Runoff Events in Central Europe from 1951 to 2002. Natural Hazards and Earth System Sciences, 9, 441-445. http://dx.doi.org/10.5194/nhess-9-441-2009

[18] Von Storch, H. and Zwiers, F.W. (1988) Reoccurrence Analysis of Climate Sensitivity Experiments. Journal of Climate, 1, 157-171. http://dx.doi.org/10.1175/1520-0442(1988)001<0157:RAOCSE $>2.0$. CO;2

[19] Ilesanmi, O.O. (1992) An Empirical Formulation of the Onset, Advance and Retreat of Rainfall in Nigeria. The Journal of Tropical Geography, 34, 15-24. 